\title{
ENYEDI GYÖRGY, A GEOGRÁFUS
}

Amikor megtudtam, hogy megtisztelnek azzal, hogy egyike leszek azoknak, akik a gödöllöi Szent István Egyetemen köszönthetik Enyedi György akadémikust 80. születésnapja alkalmából, az jutott eszembe, hogy azzal kezdem a méltatást, amit Gyurka oly szívesen tett és tesz ma is itthon és szerte a nagyvilágban, azt, hogy minden alkalmat megragad arra, hogy átadja tudását. Azt hiszem, ezt hívják iskolateremtésnek. Ezrek hallgatták. De seregnyien vagyunk tudományosan minősítettek is, akik büszkék arra, hogy Enyedi tanítványnak mondhatjuk magunkat.

Enyedi professzor hatalmas földrajzi tudással, olvasottsággal és müveltséggel rendelkezik. Már emiatt is nagyon tisztelhető és szerethető ember lenne. De amitől igazán az, az a kisugárzása, a bölcs szellemisége és a legendás szellemessége, humora. Mindebből az is következik, hogy a legbonyolultabb geográfiai problémákat is érthetően tudja kibontani és a hallgatósága elé tárni. Sőt, utánozhatatlan humora a legkínosabb helyzeteket is megoldja. Emlékszem egy esetre. Régen történt. Egyik idősebb kollegánknak Gyurka segített fordítani. A kollega valami tájföldrajzi témában tartott előadást és egymás után sorolta latinul a növények, vadvirágok neveit. Senki nem értette, de nem is érdekelt senkit. Gyurka csak ennyit mondott fordítás gyanánt: flowers. Egyébként a könnyedség jellemző a publikációira is. Bizonyára egyetértenek velem. Enyedit olvasni szakmai és irodalmi élmény. Ez csak a legnagyobbak sajátja.

Enyedi akadémikus számos nemzetközi, hazai téma kutatását végezte, vezette, és ez az izgalmas, nagyon eredményes kutatói tevékenység a jelenben is folytatódik. Kutatási célja és szemlélete nagyon világos: a térbeli társadalmi különbségek, a területi egyenlötlenségek geográfiai megközelítése, és ezt hosszú kutatói pályafutása során következetesen érvényesíti is. Ez a megközelítés a társadalomföldrajz számára számos új lehetőséget kínált.

Az első, nagy ívü földrajzi kutatási terve a dinamikus falusi térség koncepciója volt, ami az 1960-as évek végén fogalmazódott meg. Ezt az elképzelést a Nemzetközi Földrajzi Unió is támogatta, olyannyira, hogy világméretű kutatássá terebélyesedett. A kutatás vezetésével öt bízták meg. A kutatásnak az első konferenciája Szegeden volt, a szervezésben én is feladatot kaptam. Nagy élmény volt olyan kutatókkal, egyetemi oktatókkal találkozni, akik Kelet-Közép-Európában még nem jártak, ez, úgy emlékszem 1979-ben vagy 1980-ban volt.

A kifejezetten magyarországi vonatkozású témát feldolgozó számos írása közül csak egyet említek, amelyik valószínű, nem csak a geográfusok kedvelt olvasmánya, ez pedig a „Regionális folyamatok Magyarországon az átmenet időszakában” (1996). Alapmü.

Hosszú ideje kutatott témája a város. A város különféle megközelítése. A városfejlödés szakaszai. A globalizáció különféle hatásai a városokra. A kínai városok. $\mathrm{Az}$ orosz városok. Szeretne egy átfogó szintézist írni a városi világról, a mai kor 
urbanizációjáról. Isten adja meg, hogy sikerüljön. Mindannyiunk szellemi épülését fogja szolgálni.

Remélem, hogy a magyar geográfus társadalom tagjai közül igen sokan értesültek arról, hogy Enyedi György 2008-ban megkapta a Nemzetközi Földrajzi Unió (IGU) legmagasabb szakmai kitüntetését, a Lauréat d'Honneur-t. A kitüntetés elsősorban a szakmai nemzetközi tevékenység és a személyes tudományos kapcsolatteremtésben kifejtett kimagasló aktivitás elismerése. Ez a nemzetközi kapcsolatépítés 1959-ben kezdődött egy lengyelországi konferenciával, történetesen ez volt az első külföldi útja, és egyben megismerkedés a Nemzetközi Földrajzi Unióval, amelynek egyébként később alelnöke lett.

Nagyon sok alkalommal, hosszabb-rövidebb időt töltött külföldön, nagyon sok országban, számtalan városban járt kutatóként, vendégprofesszorként. Valahányszor, ha szóba kerül, elmondja, hogy mindig inkább az emberek érdekelték, de kíváncsi volt gépekre, az embert körülvevő mikrovilágra is.

Enyedi György a magyar és a nemzetközi geográfia legnagyobb formátumú személyiségeinek egyike. Adja Isten, hogy tudáskészletéből még sokáig meríthessünk.

Mészáros Rezső

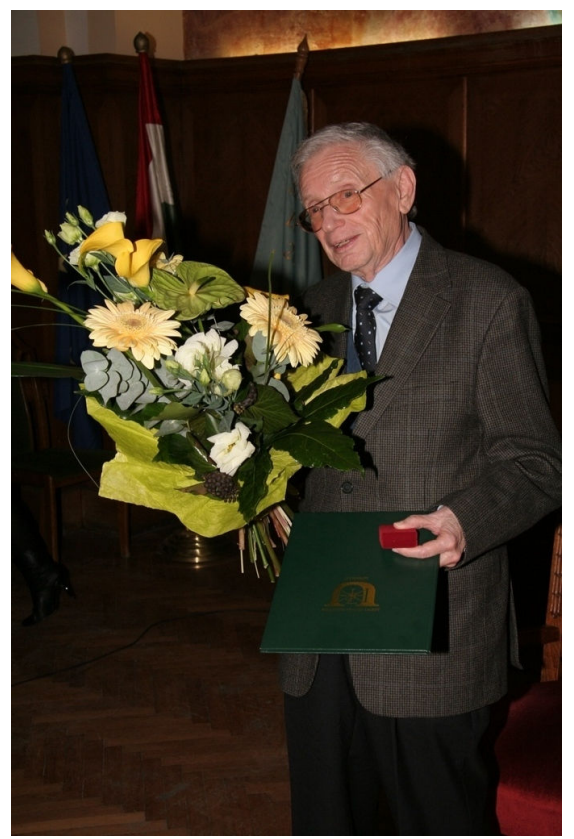

Fotó: Balázs Gusztáv. 